\title{
DIGITALCOMMONS
}

@WAYNESTATE-

Criticism

Volume 62 | Issue 1

Article 6

2020

\section{The Turn to Aesthetics in Latinx Literary and Cultural Studies}

Frances R. Aparicio

Northwestern University, frances-aparicio@northwestern.edu

Follow this and additional works at: https://digitalcommons.wayne.edu/criticism

\section{Recommended Citation}

Aparicio, Frances R. (2020) "The Turn to Aesthetics in Latinx Literary and Cultural Studies," Criticism: Vol. 62 : Iss. 1 , Article 6.

Available at: https://digitalcommons.wayne.edu/criticism/vol62/iss1/6 
THE TURN TO

AESTHETICS IN

LATINX LITERARY

AND CULTURAL

STUDIES

Frances R. Aparicio

Latinx Literature Unbound:

Undoing Ethnic Expectations by

Ralph E. Rodríquez. New York:

Fordham University Press, 2018.

Paper $\$ 30.00$, hardcover $\$ 105.00$.

\section{Abject Performances: Aesthetic}

Strategies in Latino Cultural

Production by Leticia Alvarado.

Durham, NC: Duke University

Press, 2018. Paper $\$ 25.95$, Cloth $\$ 99.95$.
Ralph E. Rodríguez's Latinx Literature Unbound: Undoing Ethnic Expectations and Leticia Alvarado's Abject Performances: Aesthetic Strategies in Latino Cultural Production textualize current scholarly approaches and debates around the role of aesthetics and formalism in reading Latinx literature, visual and performative arts, and cultural productions in general. While Latinx Literature Unbound seeks to "undo" the facile and unquestioned category of "Latinx" and "Latinidad" identity as an analytic, from a literary corpus that is heterogeneous, rich, and aesthetically dynamic, Abject Performances proposes reading "abjection as an aesthetic practice" (6) in an archive that spans from the visual texts of Ana Mendieta to the performative testimonies of Latinx Mormon subjectivities.

While both books constitute significant scholarly interventions in Latinx literary and cultural studies, they each approach the concepts of Latinidad and Latinx, as well as their selected literary and cultural texts, in significantly divergent ways. While Rodríguez aims to reject ethnicity as a category for grouping a specific literary corpus as coherent, proposing "genre" and formalism as an alternative approach for understanding Latinx literature in all of its richness, for Alvarado Latinidad is a "promising rubric 
within which to explore the offerings of abjection" (10). Their different stances as to the place and function of literature and cultural production in the framework of the long racialization of Latinx in the United States clearly demarcate their unique proposals. Rodríguez's formalist lens tends to separate the politics of our humanity and racialized lives from the linguistic craft and artistry of literary making. Alvarado's interdisciplinary approach (visual and performative arts, television, and religious testimonies) and serious engagement with racialization, queer theory, affect, and belonging position the texts studied within a larger historical framework that connects aesthetics to the politics of our lives and to the formation of our subjectivities.

Latinx Literature Unbound, as its author introduces us to the project, denounces the "cult of ethnicity" (15) that "places a burden of representation on the writer" (15). The book attempts to "break open the canon of Latinx literature and the expectations that are imposed on Latinx writers" (15), thus contesting long held notions of "authenticity" and of essentialist Latinx identity as a "blood identity" (43). The first chapter examines novels as "a universe of fictional nobodies" (24), critically engaging three instances of author identities-Danny Santiago, Brando Skyhorse, and
Eduardo Halfon-that clearly contest rigid definitions of Latinx as ethnic and biological identity. I personally remember the scandal over the real identity of Danny Santiago (Daniel James) in the 1980s and how it triggered among many Latinx literary scholars at the time discussions and debates around cultural appropriation and the racial privilege of whiteness. Rodríguez now critically undoes the narrative of Danny Santiago as ethnic fraud and exhorts us to consider that "what has been missed or avoided is a discussion of the ways the novel troubles what it is we know or think we know about the category of Latinx literature" (31). While during the mid to late 1980s as scholars we were writing to produce a corpus and claiming the requisite legitimacy to be included in the larger United States literary canon, it would have been counterproductive for us, at that moment, to question and challenge the very categories we were trying to build. The notion of Latinx literature, per se, was still in its nascent stages, barely emerging and fragile, at best. It is now, a couple of decades later, that we can safely challenge an author's identity as a central step in our national debates around the terms Latinidad and Latinx. In addition to Santiago, Rodríguez lucidly examines Brandon Skyhorse, author of Madonnas of Echo Park (2010), as an embodiment 
of "the tension between a blood identity and a lived identity" (43), thus challenging the expectations of editors and presses that Latinx authors should write about Latinx topics (47). In the case of Halfon, a displaced, "desubicado" U.S. Guatemalan writer, his novel, The Polish Boxer, about his grandfather's survival in Auschwitz, illustrates the "indeterminacy" between Halfon the author and Halfon the narrator, highlighting the gaps between authorial identities and thematic content and representativity (49-50). Continuing the "undoing" between author and text, Rodríguez's reading of Salvador Plascencia's The People of Paper in chapter 2 lucidly contests conventional references to real Latinx communities by breaking away from realist imperatives for mimetic fidelity (55). Such experimental novels exemplify the metafictional texture of the novel as an artifact, as their characters are in constant struggle over the control of the narrative. Rodríguez's critical readings that undo ethnicity as a taxonomical category for understanding Latinx literature also focus on short stories. His selection of Manuel Muñoz, Patricia Engel, and Ana Menéndez's stories exemplifies the complicated and nuanced modes in which the "we" and the "you" textualize both intimacy and distance between the narrator(s) and characters. Finally, in the last chapter, Rodríguez privileges the experimental nature of select Latinx poetry in the works of Eduardo Corral, Rosa Alcalá, and Amanda Calderón, who "in their lyric writing have freed themselves from a burden of cultural representation" (124).

In its impeccable and detailed attention to form, Rodríguez textualizes and beautifully documents the ways in which the younger generations of Latinx authors, all or most of whom have completed MFA's in elite universities, embody post-ethnic and post-identity approaches to their writings. This brings up the question of whether the freedom to separate oneself from one's cultural heritage and traditions is evidence of our gradual (and successful?) integration into U.S. institutions. Does it illustrate our engagement with the individual ethos that drives so-called American cultural values? Clearly, this post-ethnic stance is a much-needed corrective to ongoing sociological approaches to Latinx literature, where we tend to read fiction, poetry, and short stories as documented evidence, as data of our collective racialization. Yet, I would ask, is celebrating an aesthetics divorced from the larger racializing politics against U.S. Latinx our central purpose as a community of critics?

Rodríguez, in his conclusions, directly reaffirms his goal of "subtly trying to unbind Latinx 
literature from politically instrumental criticism. This criticism believes that art should be used to effect political change" (130). Coupled with his absolute rejection of Latinidad as "social fiction" (12), Rodríguez's claim for a formalistic approach that exclusively deploys literary genres as a category for grouping Latinx literature as a coherent whole goes against the grain of Latinx literature as a decolonial project. His utmost dismissal of Latinidad - as a critical concept central to understanding the larger, historical arc of our social belonging and inclusion in the academic canon-renders invisible the inter-latinx social dynamics made possible by our demographic diversification since the 1980s. The social spaces of Latinidad, already acknowledged by a variety of social scientists and cultural critics, are thus dismissed as "fiction" by monodisciplinary literary studies approaches. In addition, an exclusively formalist approach precludes our students from understanding how form and content-aesthetics-intersect with our social lives. As a scholar who taught Latinx literature since the late 1980s until 2017, I always exhorted my students to question the terms Latinx and Latinidad. Is there such a thing? What brings these at times disparate texts together? Is it the ethnicity of the writers? Is it the racialized marginalities that position them within particular articulations of resistance? Can or should we reject altogether the idea of a Latinx literary corpus and canon, once students are made aware of the ways in which canons are institutional constructions? When I teach Latinx literature, I ask students to make those decisions on their own, informed, of course, by the detailed and critical analyses of the selected course readings. While Latinx Literature Unbound is an important intervention in these debates, it also disappoints in its facile dismissal of the articulations between form, aesthetics, and the politics of resistance that, to me, constitute Latinx literature. In other words, what is our goal in teaching formalist approaches exclusively during such dangerous times for our communities in the United States? Are we suggesting that these writers lack any political, collective, or communal values? Following Rodríguez's counter-canon, we should dismiss the foundational, self-taught, and not formally educated poetic voices of the late 1960s and 1970s, due to the supposed lack of formal aesthetics in their writings. Yet, who can overlook the poetic effect of repetition in Pedro Pietri's "Puerto Rican Obituary," for instance, or the ways in which code-switching and alliteration merge in Alurista's Floricanto en Aztlán? I would insert Rodríguez's fascinating intervention into any 
discussion about Latinx literature by first recognizing the longer, historical arc that is the literary production of our writers, poets, and authors since the late 1960s, to select one particular moment of artistic renaissance. Only then, without dismissing the struggle of our pioneering literary voices that claimed to be legitimated and validated within an American canon, can we begin to understand the freedom of our current writers in embracing individualism and aesthetics together without renouncing any specific textualization of resistance.

Alvarado's book, Abject Performances, responds to Rodríguez's conundrum as cultural studies constitutes an alternative to the limits of literary studies. In contrast to Rodríguez, Leticia Alvarado deploys the critical concept of Latinidad, capitalizing on its decentered nature, reading it as a site for abject performances (9). Theorized as queer, as aesthetic, as "ungraspable alternative social organization" (11), and informed by Kant's concept of the sublime, Alvarado proposes abjection as an analytic that resists "engagement with identity politics" (10) while also highlighting "the limits of assimilation" (10). Yet, unlike Rodríguez, Alvarado engages her study of aesthetics within the larger history of "recuperative identity politics in Latinx Studies" (17). For instance, her lucid reading of Ana Mendieta's visual texts and performative bodily art resituates Mendieta within the larger context of Third World Women politics and theories, rather than just as a Cuban exile or an exclusively avant garde artist. Reinserting Mendieta within a "theoretical genealogy" (28) closer to José Muñoz's concepts of brown feeling and queer affect, as well as Judith Butler's thinking, repositions Mendieta's work closer to the sites of Latinidad than ever before. Similarly, Alvarado's proposal regarding the ASCO collective as an abject alternative to the Chicano Movement's cultural nationalism (59-60) not only brings up a reconsideration of the archive, of the queer agency in ASCO, as in the "abject jotería" that permeates the "Caca-Roaches Have No Friends" (1969) performance, but also highlights the fractured sense of internal community and group dynamics that characterized the collective (76). While her focus is on the abject affective texture of these performances and cultural productions, Alvarado does not refuse to read these texts within a longer history of Chicanx politics and arts. ASCO's aesthetics are thus, politically, an alternative response to the narrative murals of the Chicano Movement and to the heteromasculinist paradigms of cultural nationalism, while still protesting war and the city's infrastructure, among other forms 
of subordination for Chicanx subjectivities.

Alvarado then moves on to television and performance arts, placing the popular Latinx series Ugly Betty in juxtaposition with Nao Bustamante's participation in the Bravo show Work of Art. Unlike Rodríguez's decontextualized readings, Alvarado insists on the meaning of both texts "in relation to national dialogues on Latino belonging and inclusion" (91). While both texts "contribute to immigrant rights mobilizations that expose the limits of representation and a politics of respectability as well as the value of embracing queer failure as a strategy" (91), Alvarado still foregrounds the divergent social meanings of each. While the author concludes that Ugly Betty reproduces a "neoliberal multiculturalism of the 2000s" (108), that refuses to engage in the political possibilities of Betty's ugliness and that transforms Betty into a "mimetic minority beauty" (91) by the end of the series, in Nao Bustamante's performance in Work of Art, her failure as a contestant can be read, as Alvarado does, as "a mockery of the disciplinary techniques of beauty" (117). As Nao embraces "failure" and "disassociation" in this show, Alvarado also reads Bustamante's performance, "America, the Beautiful," within the context of California's xenophobic Propositions during the 1990s. Alvarado concludes that
Bustamante's performances illustrate "abjection as strategy for critique and imagining alternatives to neoliberal incorporation and nativist attacks" (111-112). Thus, abjection as aesthetics are never divorced in this book from their “political potential” (102).

Alvarado's brilliant incursion into "abjection" as a form of aesthetics concludes with the author's own autoethnographic narrative as part of her analysis of Latinx Mormon performative testimonials. After highlighting the need for religious performances to be studied through the lens of performance studies, the author offers her readers a summary of the narratives that inevitably racialize Latinx and other minority groups within the Church of Latter-Day Saints as the abject Lamanites that need to be saved by the Mormon leadership through the symbology of whitening. Focusing on the "aesthetics of abjection as the basis for religious and ambivalent belonging" (135), Alvarado analyzes the ways in which Latinx Mormon subjects "mobilize the abject Lamanite identity to negotiate the many vectors of power at work on and through them in the church and beyond" (136), and concludes with a compelling personal testimonio about her own experience growing up in Mormonism and her gradual distancing from the LDS practices 
and rituals. Abject Performances: Aesthetic Strategies in Latino Cultural Production concludes with an illuminating reading of Xandra Ibarra and Sophia Wang's performance "Cocoon," which embodies the ways in which the abject is located between "desire and disgust" (162), in that in betweenness that Alvarado also highlights at the beginning of the book. For her, Latinidad is always linked to abjection (165).

If Rodríguez's exclusive disciplinary approach to Latinx Literature led him to separate his brilliant and nuanced readings from the larger Latinx national racializing politics we have survived for decades, for Alvarado her interdisciplinary location has allowed her to fully engage with Latinidad and with the politics of abjection that clearly infuse our artistic and performative cultural productions. Our scholarship needs both types of approaches, yet it is also imperative, as we continue to sustain the project of Latinx Studies as an oppositional and decolonial politics, that we begin to identify the limits and potentialities of both.

Frances R. Aparicio is Professor Emerita at Northwestern University. She has published extensively on Latinx popular music, gender, language and identity, and on Latinx literature. Her book, Negotiating Latinidad (October 2019), examines the national negotiations of Intralatinx subjects in Chicago. She is currently writing a book about Salsa singer, Marc Anthony. 
